\title{
IAMJ
}

INTERNATIONAL AYURVEDIC MEDICAL JOURNAL

\section{A CONCEPTUAL STUDY ON ROLE OF AMRITADI KWATH IN TAMAKA SHWASA (BRONCHIAL ASTHMA)}

\author{
Harsha Radhakrishnan ${ }^{1}$, Jaya Saklani Kala², Sanjay Kumar Tripathi ${ }^{3}$ \\ ${ }^{1} \mathrm{MD} 2{ }^{\text {nd }}$ year, Dept. of Kaya Chikitsa, Rishikul Campus, UAU Haridwar, Uttarakhand, India \\ ${ }^{2}$ Associate Professor, Dept. of Kaya Chikitsa, Rishikul Campus, UAU Haridwar, Uttarakhand, India \\ ${ }^{3}$ Prof, Dept. of Kaya Chikitsa, Rishikul Campus, UAU Haridwar, Uttarakhand, India
}

Corresponding Author: chinnukk494@gmail.com

\section{https: / / doi.org/10.46607/iamj2908112020}

(Published online: November 2020)

Open Access

(C) International Ayurvedic Medical Journal, India 2020

Article Received: 30/10/2020 - Peer Reviewed: 10/11/2020 - Accepted for Publication: 17/11/2020

Check for updates

\section{ABSTRACT}

Objective: Tamaka Shwasa is a Vatakaphaja Vyadhi originating from Pitta Sthana and manifesting through Pranavaha Srotas. Vata gets obstructed by Kapha and travels in Pratiloma Gati, thus causing the disease entity called Tamaka Shwasa. Tamaka Shwasa in Ayurvedic classics seems to be identical with the description of Bronchial Asthma in modern medicine. Bronchial Asthma is a major global health problem, which can affect the population irrespective of age, sex, economic status, etc. Method: References regarding Amritadi kwath are collected from Cakradatta, and further details regarding the constituent drugs are collected from textbooks, PubMed Central, published research papers and previous work done. Result: As per the data collected, Bronchial Asthma when treated with Amritadi kwath will be effective in relieving the symptoms in patients. Due to increasing prevalence, chronic, intermittent and inflammatory nature of the disease and also for better management of Tamaka Shwasa patients; it is a need of hour for innovative research regarding this topic. Conclusion: Amritadi kwath will be effective in improving pulmonary functions in Bronchial Asthma. Here we can conclude that Ayurvedic medicines will be a better choice in treating Bronchial Asthma in the near future.

Keywords: Tamaka Shwasa, Bronchial Asthma, Amritadi kwath. 


\section{INTRODUCTION}

Shwasa is the major disease entity affecting Pranavaha Srotas. It is of five types namely Maha Shwasa, Urdhva Shwasa, Chinna Shwasa, Tamaka Shwasa and Kshudra Shwasa. Tamaka Shwasa one among them, is caused by Vata moving in reverse order pervades the channels of vital breath, afflicts the neck and head, and stimulates Kapha to cause Pinasa. This Vata, thus obstructed, produces Tamaka Shwasa ${ }^{l}$. It is well known for its episodic and chronic course which comes under the life-threatening disease which afflicts the human race. Due to many etiological factors, movement of air through Pranavaha Srotas is hampered in this disease resulting in difficulty for breathing.

Tamaka Shwasa, in Ayurveda is similar to the description of Bronchial Asthma in modern medicine. Bronchial Asthma is one of the major global health problems, of current era. At present, Asthma is reported in $1.2-6.3 \%$ adults in most countries. About 300 million people worldwide suffering from Asthma and the number has risen by around $50 \%$ in the last decade. There are only a few studies from India on epidemiology of Asthma. Overall burden of Asthma in India is estimated to be more than 15 million patients. Five percent of children under 11 years have Asthma in India.

The Global Initiative for Asthma has proposed a descriptive definition of Asthma. Asthma is a chronic inflammatory disorder of the airways associated with airway hyper responsiveness that leads to recurrent episodes of wheezing, breathlessness, chest tightness and coughing, particularly at night or in the early morning. Irrespective of age and gender it affects all categories of people and cause serious impairment in the quality of life of the patient. Current estimate suggests that Asthma affects 300 million people worldwide and an additional 100 million people will be diagnosed by $2025^{2}$.

Drawbacks of current treatment according to modern science for Asthma are limited efficacy, failure to reduce mortality, adverse effects of drugs and issues regarding availability and cost.

Even though Tamaka Shwasa is considered as a Yapya Vyadhi ${ }^{3}$, it becomes Sadhya if it is of recent onset and when the Rogi Bala is more. Early diagnosis and treatment are essential to minimize further progression. Ayurvedic treatment is a hope for the patients combating with Asthmatic problems.

\section{Tamaka Shwasa:}

Nidana:

Acharya Caraka has mentioned common nidana for all the five types of Shwasa..Tamaka Shwasa occurs mainly as a result of Vata and Kapha Prakopa Nidanas. For convenience, the causative factors can be categorized into: -

1. Aharaja Nidana: Rukshanna, Vishamanna, Nishpava, Masha, Pinyaka, Tila Taila, Pishta, Shaluka, Vishtambhi-Vishtambhi- Guru bhojan, Jalaja- Anupa mamsa, Dadhi, AmaKshira, Shleshmala ahara

2. Viharaja Nidana: Rajas, Dhuma, Vata, Seeta sthana ambu sevan, Vyayama, Gramyadharma, Adhwa, AtiApatarpana, Marmaghata, Suddhyatiyoga, Abhishyandi upachara, Kanta-Ura Pratighata

3. Nidanarthakara Rogas: Amapradosha, Anaha, Daurbalya, Atisara, Jwara, Chardi, Pratishyaya, Kshata, Kshaya, Udavarta, Visuchika, Alasaka, Pandu, Visha, Vibandha

4. Vyanjaka Hetu: Megha, Ambu, SeetaPragvatha, Sleshmala foods and regimens ${ }^{4}$. 


\section{$\underline{\text { Samprapti: }^{5}}$}

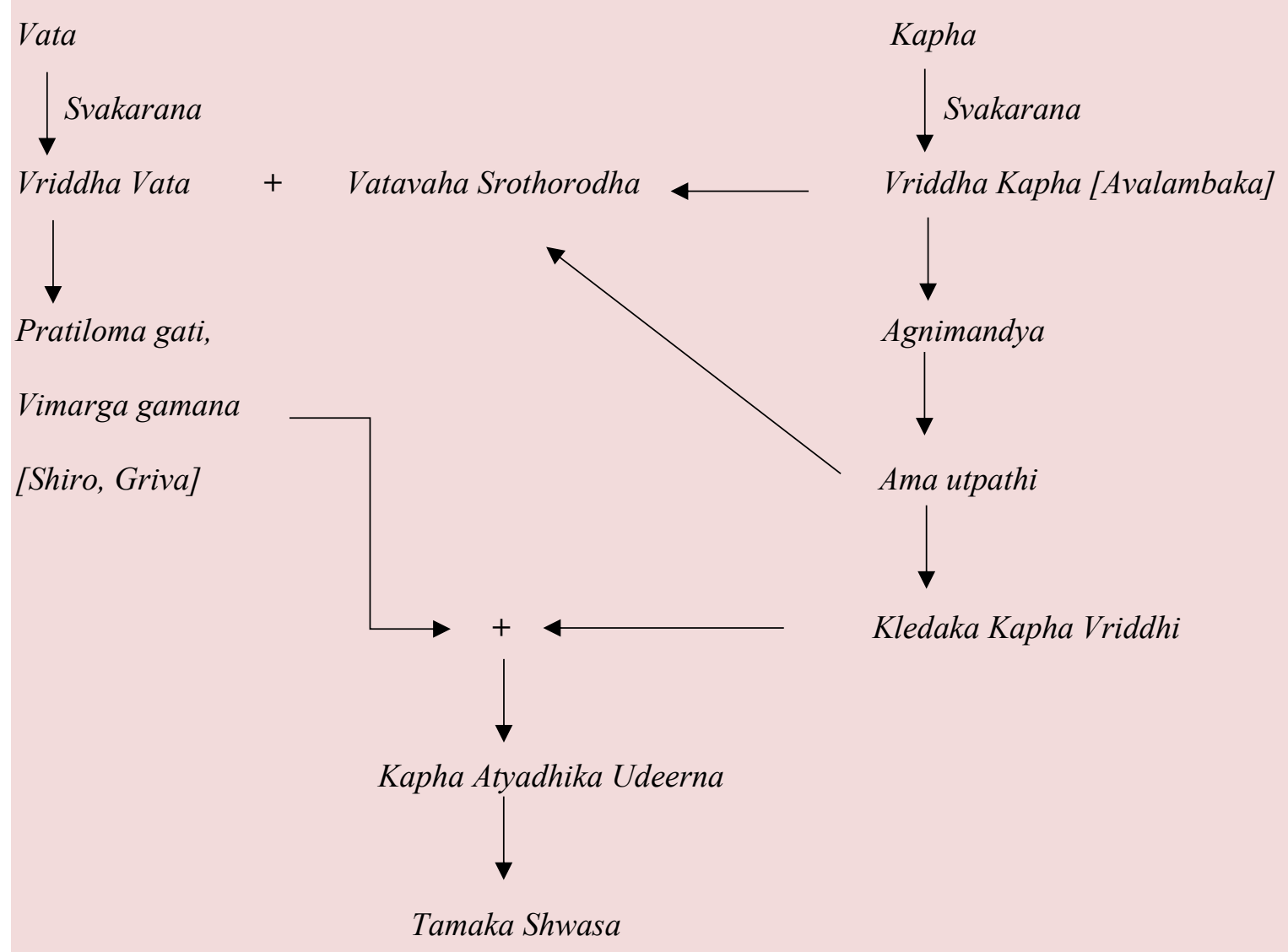

Purvarupa: The purvarupa of Shwasa Roga is also applicable to Tamaka Shwasa. According to Acharya Caraka the purvarupa are: -

Anaha, Parsvasula, Hritpida, Pranavilomata ${ }^{6}$.

Rupa: The main symptoms are Pinasa, Ghurghuraka, Ativa tivra vega Shwasa, Vegayukta Kasa, Pratamyati, Sleshma vimokshante muhurt labhate sukham, Kanthodwansa, Anidra, Asinolabhatesaukhyam, Ushnabhinandan, Lalate sweda, Visushkasya ${ }^{7}$.

Ayurvedic Management of Tamaka Shwasa in brief:

- Nidanaparivarjana: Avoidance of causative factors.

- Samsodhana: Snigdhasweda, Vamana, Dhumapana, Virechana [Tamake tu Virechana], Nasya.
- Samshamana: Shamana yogas and treatment will lessen the upadravas.

In general; medicines, drinks, foods must be Kapha Vatagna, Ushna and Vatanulomana in nature. Ekanthika Chikitsa should not be done [Since Vata and Kapha are opposite in nature.] The administration of ingredients which alleviate Vata but may aggravate Kapha can, if necessary, be used in exceptional circumstances ${ }^{8}$.

\section{Amritadi Kwath:}

The ingredients of Amritadi Kwath are Amrita, Sunti, Bharngi, Kantkari and Tulsi which is administered along with Pippali Churna as Anupan. It is effective in Shwasa and Kasa'. 
Rasapanchaka ${ }^{10}$ and Pharmacological Action of Drugs in Amritadi Kwath:

\begin{tabular}{|c|c|c|c|c|c|c|c|}
\hline Drug & Rasa & Guna & Virya & Vipaka & $\begin{array}{l}\text { Doshag- } \\
\text { nata }\end{array}$ & Aushadi Karma & $\begin{array}{l}\text { Pharmacological ac- } \\
\text { tion }\end{array}$ \\
\hline Amrita & $\begin{array}{l}\text { Tikta, } \\
\text { Kashaya }\end{array}$ & $\begin{array}{l}\text { Guru, } \\
\text { Snigdha }\end{array}$ & Ushna & Madhura & $\begin{array}{l}\text { Tridosha } \\
\text { shamaka }\end{array}$ & $\begin{array}{l}\text { Deepan, Pachan, Anu- } \\
\text { loman, } \\
\text { Vedhanasthapan, Ra- } \\
\text { sayan }\end{array}$ & $\begin{array}{l}\text { antiallergic, antioxi- } \\
\text { dant, } \\
\text { anti-inflammatory, } \\
\text { immunomodulatory }\end{array}$ \\
\hline$\underline{\text { Sunti }}$ & Katu & $\begin{array}{l}\text { Laghu, } \\
\text { Snigdha }\end{array}$ & Ushna & Madhura & $\begin{array}{l}\text { Kapha- } \\
\text { Vata } \\
\text { shamaka }\end{array}$ & $\begin{array}{l}\text { Shwasahar, } \\
\text { Sothahar, Seetaprasa- } \\
\text { man, Vedhanasthapan, } \\
\text { Deepan, Pachan, } \\
\text { Vatanuloman, } \\
\text { Soolaprasaman, Ama- } \\
\text { pachan, Srotho- } \\
\text { rodhanivaran }\end{array}$ & $\begin{array}{l}\text { antioxidant, } \\
\text { anti-inflammatory, } \\
\text { immunomodula- } \\
\text { tory, } \\
\text { anti-histaminic, } \\
\text { antitussive, } \\
\text { bronchodilator, } \\
\text { anti-asthmatic } \\
\text { 13 }\end{array}$ \\
\hline Bharngi & $\begin{array}{l}\text { Tikta, } \\
\text { Katu }\end{array}$ & $\begin{array}{l}\text { Laghu } \\
\text { Ruksha }\end{array}$ & Ushna & Katu & $\begin{array}{l}\text { Kapha- } \\
\text { Vata } \\
\text { shamaka }\end{array}$ & $\begin{array}{l}\text { Shwasahar, } \\
\text { Kasahar, Sothahar, } \\
\text { Deepan, Pachan, Anu- } \\
\text { loman, Amapachan }\end{array}$ & $\begin{array}{l}\text { antiallergic, antioxi- } \\
\text { dant, } \\
\text { anti-inflammatory, } \\
\text { anti-histaminic, } \\
\text { anti-asthmatic, } \\
\text { mast cell stabiliza- } \\
\text { tion }^{14}\end{array}$ \\
\hline$\underline{\text { Kantkari }}$ & $\begin{array}{l}\text { Tikta, } \\
\text { Katu }\end{array}$ & $\begin{array}{l}\text { Laghu } \\
\text { Ruksha } \\
\text { Teekshna }\end{array}$ & Ushna & Katu & $\begin{array}{l}\text { Kapha- } \\
\text { Vata } \\
\text { shamaka }\end{array}$ & $\begin{array}{l}\text { Kasahar, } \\
\text { Kanthya, Shwasahar, } \\
\text { Hikkanigrahan, } \\
\text { Deepan, Pachan, So- } \\
\text { thahar, } \\
\text { Vedhanastapan }\end{array}$ & $\begin{array}{l}\text { anti-asthmatic, } \\
\text { anti-inflammatory, } \\
\text { anti-histaminic, } \\
\text { antiallergic, } \\
\text { mast cell stabiliza- } \\
\text { tion, } \\
\text { bronchodilator }{ }^{15} \text {, } \\
\text { expectorant }^{16}\end{array}$ \\
\hline$\underline{\text { Tulsi }}$ & $\begin{array}{l}\text { Tikta, } \\
\text { Katu }\end{array}$ & $\begin{array}{l}\text { Laghu } \\
\text { Ruksha }\end{array}$ & Ushna & Katu & $\begin{array}{l}\text { Kapha - } \\
\text { Vata } \\
\text { Shamaka }\end{array}$ & $\begin{array}{l}\text { Shwasahara, } \\
\text { Kasahara, } \\
\text { Sothahar, } \\
\text { Vedhanahar, } \\
\text { Seetaprasaman, } \\
\text { Deepan,Pachan,Anu- } \\
\text { loman }\end{array}$ & $\begin{array}{l}\text { antioxidant, } \\
\text { anti-inflammatory, } \\
\text { immunomodula- } \\
\text { tory }^{17} \text {, } \\
\text { antiallergic, } \\
\text { antitussive, } \\
\text { antispasmodic }^{18}\end{array}$ \\
\hline$\frac{\text { Anupan: }}{\text { Pippali }}$ & Katu & $\begin{array}{l}\text { Laghu, } \\
\text { Snigdha, } \\
\text { Teekshna }\end{array}$ & $\begin{array}{l}\text { Anushna } \\
\text { seeta }\end{array}$ & Madhura & $\begin{array}{l}\text { Kapha- } \\
\text { Vata } \\
\text { Shamaka }\end{array}$ & $\begin{array}{l}\text { Deepan, Vatanulo- } \\
\text { man, Soolaprasaman, } \\
\text { Kasahar, } \\
\text { Shwasahar, } \\
\text { Hikkanigrahan, Ra- } \\
\text { sayan }\end{array}$ & $\begin{array}{l}\text { antispasmodic, } \\
\text { anti-inflammatory, } \\
\text { immunostimulatory, } \\
\text { cough suppressor }^{19}\end{array}$ \\
\hline
\end{tabular}




\section{DISCUSSION}

On analysing the above facts, it can be said that Amritadi Kwath will be an excellent choice in treating Bronchial Asthma. Tikta rasa ${ }^{20}$ of the drugs has Kaphashamana and Kledahara properties. Most of the drugs have Katu rasa ${ }^{21}$, Ushna virya and Katu vipaka which helps in reducing excess Kapha and Kleda and moreover providing Srothosodhana. The accumulated secretions in the respiratory pathway thus can be cleared and Srothosudhi can be attained easily. Ushna virya also helps in bronchodialation which causes the enhancement of air circulation in the respiratory pathways. It also strengthens the Agni which is inevitable for the normal functioning of the body.

The contents of the Amritadi Kwath are mainly Vata Kaphahara, thus pacifying the predominant doshas in Tamaka Shwasa. Since Ama contributes a major role in Samprapti these drugs having Deepan, Pachan and Vatanuloman properties will be very effective. Sothahar drugs will clear the passages and makes the breathing effortless. Almost all the drugs are having Shwasahar and Kasahar properties.

Pharmacological actions of drugs in Amritadi Kwath which are significant in treatment of Tamaka Shwasa are: -

- Antispasmodic activity which helps in reducing the bronchospasm. $^{22}$

- Expectorants which helps in removing excessive secretions in the airways. ${ }^{23}$

- Antioxidant action helps in minimizing the tissue damage. ${ }^{24}$

- Anti-inflammatory action which may reduce mucosal inflammation. ${ }^{25}$

- Anti-asthmatic action which prevents asthma attacks. ${ }^{26}$

- Bronchodilator action which relaxes the muscles in lungs and widens the airways. ${ }^{27}$

- Antitussive action that prevents or relieves cough. ${ }^{28}$

- Antihistaminic and Antiallergic action that relieves symptoms of allergy. ${ }^{29}$

- Immunomodulatory action that regulates or normalises the immune system. ${ }^{30}$

- Mast cell stabilisation which means blocking the mast cell degranulation, stabilising the cell and thereby preventing the release of histamine and re-

lated mediators which causes allergy. ${ }^{31}$

So, it is clear that Amritadi Kwath will have great efficacy if administered in Tamaka Shwasa.

\section{CONCLUSION}

Basically, Tamaka Shwasa is VataKaphatmaka in nature which has Agnimandya and Ama as the contributing factors to the Samprapti. Here the drugs of Amritadi Kwath are VataKaphagna, Deepan, Pachan and Vatanuloman which will be helpful in Samprapti vighatana of Tamaka Shwasa. The pharmacological actions of drugs of Amritadi Kwath like anti-asthmatic, anti-inflammatory, anti-histaminic, antiallergic, mast cell stabilization, bronchodilator, expectorant actions etc., shows the efficacy of the drug. So, Amritadi Kwath meets all the qualities needed for a Shwasahar yoga. Thus, we can conclude that Amritadi Kwath will be effective in improving the Pulmonary functions in Bronchial Asthma. It is crystal clear that, Ayurvedic management can provide better alternative to Allopathic drugs in treating Tamaka Shwasa (Bronchial Asthma).

\section{REFERENCES}

1. Agnivesa, Caraka Samhita (vol IV). Translated by Dr.Ram Karan Sharma,Vaidya Bhagwan Dash. Varanasi: Chowkhamba Sanskrit Series Office; Reprint edition- 2011.p 131.

2. Harrison's Principles of Internal Medicine (vol II). USA: Mc Graw Hill Companies; 17th edition 2005.p 1596.

3. Vagbhata. Ashtanga Hrdayam (vol II). Translated by Prof. K. R. Srikantha Murthy. Varanasi: Chowkhamba Krishnadas Academy; Reprint edition-2012.p 38.

4. Agnivesa, Caraka Samhita (vol IV). Translated by Dr. Ram Karan Sharma,Vaidya Bhagwan Dash. Varanasi: Chowkhamba Sanskrit Series Office; Reprint edition- 2011.p 131.

5. Professor Ajay Kumar Sharma. Kayachikitsa (vol II). Varanasi: Chaukhambha Orientalia; 2014.p 18.

6. Agnivesa, Caraka Samhita (vol IV). Translated by Dr. Ram Karan Sharma, Vaidya Bhagwan Dash. Varanasi: Chowkhamba Sanskrit Series Office; Reprint edition- 2011.p 121.

7. Agnivesa, Caraka Samhita (vol IV). Translated by Dr. Ram Karan Sharma, Vaidya Bhagwan Dash. Varanasi: Chowkhamba Sanskrit Series Office; Reprint edition- 2011.p 131. 
8. Agnivesa, Caraka Samhita (vol IV). Translated by Dr. Ram Karan Sharma, Vaidya Bhagwan Dash. Varanasi: Chowkhamba Sanskrit Series Office; Reprint edition- 2011.p 153.

9. Sri Cakrapanidatta. Cakradatta. Edited and Translated by Priyavrat Sharma. Varanasi: Chaukhambha Orientalia; $3^{\text {rd }}$ edition-2002.p 146.

10. Professor. P. V. Sharma. Dravyaguna Vigyan (vol II). Varanasi: Chaukhambha Bharati Academy; Reprint edition-2019.

11. Avnish K. Upadhyay, Kaushal Kumar, Arvind $\mathrm{Ku}-$ mar, and Hari, Tinospora cordifolia (Willd.) Hook. f. and Thoms. (Guduchi) - validation of the Ayurvedic pharmacology through experimental and clinical studies, International Journal of Ayurvedic Research, Vol I [PubMed Central]

12. Amit G. Patel, M.B. Nariya, V.J. Shukla, B.R. Patel, Review on Trisama- an unexplored ancient Ayurvedic formulation, Journal of Ayurvedic and Herbal Medicine 2017, [ ISSN: 2454-5023]

13. Vd. Rohit Mehta, Shunti arka as dhumapana in the management of Tamaka Shwasa w.s.r. to bronchial asthmaa conceptualized study, European Journal of Biomedical AND Pharmaceutical sciences, [ISSN 2349-8870], Volume: 4

14. Poornima BS, Prakash L Hegde, Pradeep, Harini A, Pharmacological review on Clerodendrum serratum Linn. Moon, Journal of Pharmacognosy and Phytochemistry, [ E-ISSN: 2278-4136, P-ISSN: 2349-8234]

15. Yogita V. Dalvi. The Comprehensive Review on Kantakari Plant. Asian J. Res. Pharm. Sci. 2018; 8(3):140144. doi: 10.5958/2231-5659.2018.00025.5

16. Roshy Joseph C, Ilanchezhian R, Patgiri BJ, Therapeutic potentials of Kantakari (Solanum xanthocarpum Schrad. \& Wendl.), Ayurpharm Int J Ayur Alli Sci., Vol.1, No.2 (2012), [ ISSN: 2278-4772]

17. Kavyashree M, Harini A, Hegde PL, Pradeep D. A review on Tulasi (Ocimum sanctum Linn.). JDDT[Internet]. 15Apr.2019, Vol 9

18. Marc Maurice Cohen, Tulsi - Ocimum sanctum: A herb for all reasons, Ayurveda Integr Med. 2014 OctDec; 5(4): 251-259. doi: 10.4103/0975-9476.146554

19. Sadhana Singh, Apurva Priyadarshi, Brijesh Singh and Poonam Sharma, Pharmacognostical and phytochemical analysis of Pippali (Piper longum Linn.), PharmaInnovation 2018

20. Vagbhata. Ashtanga Hrdayam (Verses with Index). Compiled by Dr. T. Sreekumar. Thrissur: Publication Department of Harisree Hospital; $1^{\text {st }}$ edition-2011.p 83.
21. Vagbhata. Ashtanga Hrdayam (Verses with Index). Compiled by Dr. T. Sreekumar. Thrissur: Publication Department of Harisree Hospital; $1^{\text {st }}$ edition-2011.p 83.

22. David I. Macht And Giu-Ching Ting, A Study Of Antispasmodic Drugs On The Bronchus, Journal of Pharmacology and Experimental Therapeutics 1 December 1921, Vol 18, Issue 5

23. https://www.drugs.com/drug-class/expectorants.html, date of access:25/10/2020

24. https://www.medicalnewstoday.com/articles/301506, date of access: $17 / 11 / 2020$

25. https://en.wikipedia.org/wiki/Anti-inflammatory, date of access: $17 / 11 / 2020$

26. http://www.healthofchildren.com/A/AntiasthmaticDrugs.html, date of access:25/10/2020

27. https://www.nhs.uk/conditions/bronchodilators/, date of access:25/10/2020

28. https://www.google.com/search?client=ms-androidvivo\&sxsrf $=$ ALeKk03FtBf8JeClRQE0MnH549S7tTN 9kQ\%3A1603645775396\&ei=T7GVX8jWF9Go9QPa ho3oAg\&q=antitussive\&oq=antitu\&gs_lcp=ChNtb2JpbGUtZ3dzLXdpeilzZXJwEAEYADIKCAAQsQMQyQMQQzICCAAyAggAMgIIADICCAAyAggAMgIIADICCAA6BwgAEEcQsAM6BwgjEOoCECc6BAgjECc6BAgAEEM6BwgAEMkDEEM6CAgAELEDEIMBOgUIA-

BCxA1C2sRFY tgRYMHIEWgDcAB4AIAB8wGIAZAKkgEFMC4xLjWYAQCgAQGwAQ_IAQjAAQE\&sclient=mobile-gwswiz-serp, date of access:25/10/2020

29. https://www.merriam-webster.com/dictionary/anti-allergic, date of access: $17 / 11 / 2020$

30. https://www.aaaai.org/conditions-and-treatments/conditions-dictionary/immunomodulators, date of access:25/10/2020

31. https://en.wikipedia.org/wiki/Mast_cell_stabilizer, date of access:25/10/2020

\section{Source of Support: Nil Conflict of Interest: None Declared}

How to cite this URL: Harsha Radhakrishnan et al: A Conceptual Study On Role Of Amritadi Kwath In Tamaka Shwasa (Bronchial Asthma). International Ayurvedic Medical Journal \{online\} 2020 \{cited November, 2020\} Available from: http://www.iamj.in/posts/images/upload/5141_5146.pdf 